https://doi.org/10.31426/ijamsr.2018.1.3.134

International Journal of

Advanced Multidisciplinary Scientific Research (IJAMSR) ISSN:2581-4281

I J A M S R

\title{
ENGLISH LANGUAGE LEARNING SYSTEM AT HIGHER SECONDARY LEVEL IN BANGLADESH: CHALLENGES AND OPPORTUNITIES
}

\author{
Sheikh Alauddin', Mizanur Rahman Jewel ${ }^{2}$
}

Asst.Professor \& Head in Charge, Dept.of.English, Bangladesh University, Dhaka, Bangladesh. Senior Lecturer, Dept of English, Bangladesh International School, Riyadh, Saudi Arabia alauddinbu1957@gmail.com

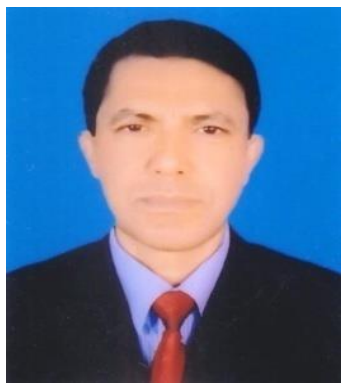

SHEIKH ALAUDDIN

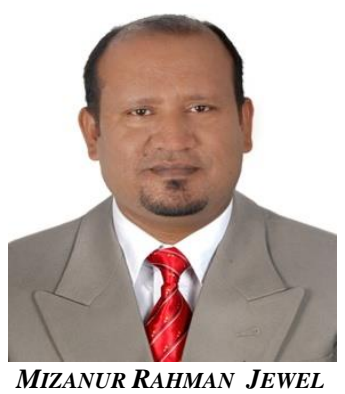

Keywords: Curriculum, Higher Secondary Education,

Learners Need, Communicative Competence, Learning System In College Level In Bangladesh.

\begin{abstract}
A B S T R A C T
English is studied in Bangladesh as a compulsory subject in our curriculum to materialize specific purpose, e.g. to get overseas employment, to help to promote foreign trade and commerce and higher education facilities. English is taught also to enable learners to be acquainted with the foreign culture, tradition, history and the country in general of the target language and also to pursue knowledge and pleasure about the world. Learners study English for 14 years. During this long period English and Bengali are considered by the same weight. The aim of this paper is to describe the context of English Learning System in Bangladesh. It is an attempt to find out the present situation and problems within it, and to conclude by making some proposals and recommendation towards the improvement of the situation. The paper will also focus on the aims and objectives of LSEL in colleges of Dhaka City that is attempting to minimize the problems in learning situation of LSEL in Bangladesh. By doing this survey I have found that very few colleges have concern on English Language Learning System but most of the colleges neither are not concerned about this factor. The research has been taken based on the primary data collected from various renowned Higher Secondary Level institutions of Dhaka city. Data collected through a questionnaire prepared based on the needs of research. The questionnaire has been designed so that the necessary data for research are collected and the detailed analysis can be made and can be reached a pragmatic conclusion. Sampling consists of seventy students among the population of the data. Sampling was done on a random basis and presents the whole population in a significant way.
\end{abstract}

Citation: Sheikh Alauddin Mizanur Rahman Jewel (2018). English Language Learning System At Higher Secondary Level In Bangladesh: Challenges And Opportunities. International Journal of Advanced Multidisciplinary Scientific Research (IJAMSR ) ISSN:2581-4281 Vol 1, Issue 3, May, 2018, \#Art.134, pp49-55

\section{Introduction}

The aim of this paper is to describe the context of English Learning System in Bangladesh. It is an attempt to find out the present situation and problems within it, and to conclude by making some proposals and recommendation towards the improvement of the situation. The paper will also focus on the aims and objectives of LSEL in colleges of Dhaka City that is attempting to minimize the problems in learning situation of LSEL in Bangladesh. By doing this survey I have found that very few colleges have concern on English Language Learning System but most of the colleges neither are not concerned about this factor. 


\section{International Journal of Advanced Multidisciplinary Scientific Research (IJAMSR) ISSN:2581-4281}

\section{Statement Of The Problem}

English language learning is a burning issue all over the world now-a-days. To cope with the present business world, almost every country in the globe is now trying to achieve efficiency on English language. Bangladesh is not an exception in doing so. Though the GrammarTranslation method previously dominated all over the world, now it is the practice of following communicative method. Bangladesh is also following the current trends and practices of language learning.

\section{Rationale Of Study}

The sole aim of CLT-communicative language teaching is to achieve communicative competence of the learners. In Bangladesh, this methodology is too introduced to achieve this goal. But recent studies have found that there are many problems existing within it. That's why there are some problems for the proper implementation of CLT in the country. The situation is very worse in secondary and higher secondary levels in our country. Though many research studies have been undertaken in secondary level, there is less study in case of higher secondary level. Based on the current situation, I have undertaken my study in higher secondary level. And my research interest is in some of the reputed colleges of Dhaka city.

\section{Objective:}

The followings are the underlying objectives of the study-

- To describe the context of learning system of English language in Bangladesh.

- To analyze the present situations and problems within it.

- To make recommendations to improve the existing situations of English language learning in Bangladesh.

\section{Review Of Literature}

English is studied in Bangladesh as a compulsory subject in our curriculum to materialize specific purpose, e.g. to get overseas employment, to help to promote foreign trade and commerce and facilities in higher education. English is taught also to enable learners to be acquainted with the foreign culture, tradition, history and the country, in general, of the target language and also to pursue knowledge and pleasure about the world. Learners study English for 14 years. During this long period, English and Bengali are considered by the same weight.

The National Syllabus and Curriculum Committee has specified that The English Language syllabus aims to focus on the four skills of listening, speaking, reading and writing as learner-centered activities within communicative contexts' (new Syllabus for Secondary \& Higher Secondary levels, NCTB,1995). But in reality, when English is used in a class, students are guided by the teacher to focus on teaching, reading, translation and writing as there are the exam-oriented skills (Hoque et al, 1997).

The question of learning English at various stages of our education is important as the system has been changed again on the basis of research, symposium, seminar and many proposals offered by the experts. The educated or even fairly educated people had to use English for office, professional, educational and other purposes. However, after the war of liberation in 1971 in independent Bangladesh the official status of the English language changed to that of a foreign language. In this monolingual country people could do almost everything in Bengali, thus not using English in real life communication, they started facing problems when they were required to communicate in English. However English is used in many government, semi government and private organizations along with Bengali.

\section{Methodology}

This research was basically undertaken on LSEL (learning system of the English Language) of different Higher Secondary Colleges of Dhaka, the capital city of Bangladesh. To materialize this research I have prepared a survey questionnaire including twelve questions for the students of English studying students in the various colleges of Dhaka city. This questionnaire is prepared on the basis of yes/no answering method. 70 students participated in this survey. After collecting all the answers of the students I have stated a picture of LSEL statically and graphically that reflects the present situation of the LSEL. The names of the colleges of Dhaka city which are taken from surveys are stated below:

- Ideal School \& College, Motijheel, Dhaka-1000

- Notre Dame College, Arambagh, Motijheel, Dhaka-1000

- Motijheel Model High School \& College, Dhaka-1000 
https://doi.org/10.31426/ijamsr.2018.1.3.134

\section{International Journal of Advanced Multidisciplinary Scientific Research (IJAMSR) ISSN:2581-4281}

- Dhaka City College, Dhanmondi, Dhaka

- National Ideal School \& College, Khilgaon.

Data Anlysis

The result of the research has been analyzed based on the primary data collected from various renowned Higher Secondary Level institutions of Dhaka city. Data collected through a questionnaire prepared based on the needs of the research. The questionnaire has been designed so that the necessary data for research are collected and the detailed analysis can be made and can be reached at a pragmatic conclusion. Sampling consists of seventy students among the population of the data. Sampling was done on a random basis and presents the whole population in a significant way.

\section{Result \& Discussion}

The detailed analysis of the survey has been presented below:

The Question Number 1 and response is as follows:

Which method of learning English is followed at H.S.C level in your college?

\begin{tabular}{|c|c|c|c|}
\hline \multirow{2}{*}{ Method } & \multicolumn{3}{|c|}{ Answer } \\
\cline { 2 - 4 } & Yes & No & $\begin{array}{c}\text { Total } \\
\text { Respondent }\end{array}$ \\
\hline $\begin{array}{c}\text { Grammar-translation } \\
\text { method }\end{array}$ & 0 & 0 & 70 \\
\hline \multicolumn{1}{|c|}{$\begin{array}{c}\text { Direct } \\
\text { method }\end{array}$} & 0 & 0 & 70 \\
\hline $\begin{array}{l}\text { Communicative } \\
\text { method }\end{array}$ & 70 & 0 & 70 \\
\hline Audi-lingual method & 0 & 0 & 70 \\
\hline
\end{tabular}

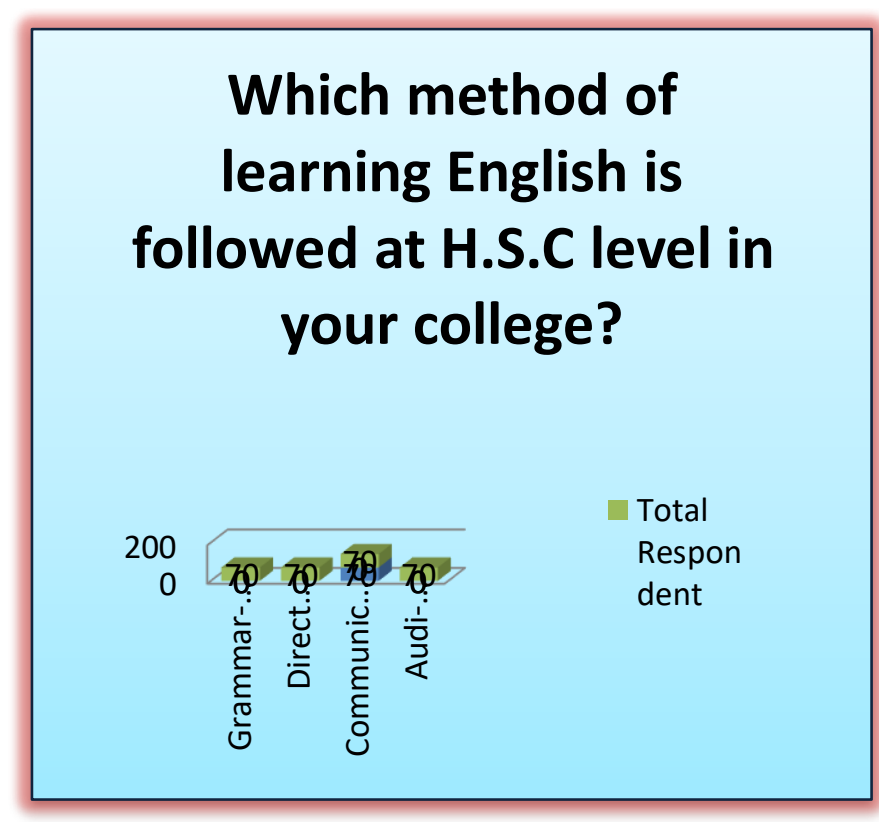

\section{Response:}

Seventy students answered this question in their answer script which was provided to them directly. $100 \%$ students agreed that communicative method is being followed in their college.

The Question Number 2 and response is as follows:

Does your college follow existing communicative method to develop your English proficiency?

\begin{tabular}{|c|c|c|}
\hline Yes & No & Total Respondent \\
\hline 65 & 5 & 70 \\
\hline
\end{tabular}

Response: I got the answer "Yes" from 92.85\% students and they agreed their college follow the existing communicative method in their class.

The Question Number 3 and response is as follows: 
https://doi.org/10.31426/ijamsr.2018.1.3.134

I J A M S R

\section{International Journal of}

Advanced Multidisciplinary Scientific Research (IJAMSR) ISSN:2581-4281

Do you think that students studying at the college level can gain efficiency through a communicative process?

Response: I got the answer "yes" from $48.58 \%$ students and "No" from $51.42 \%$ students.

\begin{tabular}{|c|c|c|}
\hline \multicolumn{3}{|c|}{ Answer } \\
\hline Yes & No & Total Respondent \\
\hline 34 & 36 & 70 \\
\hline
\end{tabular}

Do you think that students studying in the college level can gain efficiency through communicative process?

$$
\begin{array}{cc}
\text { Total } \\
70
\end{array} \text { Po }_{34}^{\text {No }}
$$

The Question Number 4 and responses are as

follows:

Do you think that Grammar Translation method is more useful than communicative method?

\begin{tabular}{|c|c|c|}
\hline \multicolumn{3}{|c|}{ Answer } \\
\hline Yes & No & Total Respondent \\
\hline 32 & 38 & 70 \\
\hline
\end{tabular}

Response: $45.72 \%$ students agreed that Grammar translation method was more useful than communicative method. 54.28\% students think that existing communicative method is more useful to them.

The Question Number 5 and response is as follows: Does your college provide sufficient facilities like English club or English foundation course in improving your skill following the communicative method?

\begin{tabular}{|c|c|c|}
\hline \multicolumn{3}{|c|}{ Answer } \\
\hline Yes & No & Total Respondent \\
\hline 10 & 60 & 70 \\
\hline
\end{tabular}

\section{Response:}

Only $14.28 \%$ students agreed that their college provides sufficient facilities like English club or English foundation course in improving their skill following the communicative method. $85.72 \%$ students were deprived of these facilities.

The Question Number 6 and responses are as follows:

Do you think that many students get encouraged in studying English through the process like the communicative method?

\begin{tabular}{|c|c|c|}
\hline \multicolumn{2}{|c|}{ Answer } \\
\hline Yes & No & Total Respondent \\
\hline 26 & 44 & 70 \\
\hline
\end{tabular}


https://doi.org/10.31426/ijamsr.2018.1.3.134

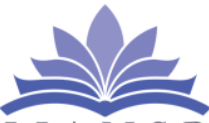

I J A M S R

\section{International Journal of Advanced Multidisciplinary Scientific Research (IJAMSR) ISSN:2581-4281}

Do you think that many students get encouraged in studying English through the process like communicative method?

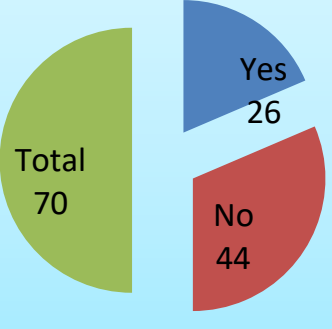

\section{Response:}

According to the answer $37.15 \%$ students agreed that the communicative method encourages in studying English. But $62.85 \%$ students did not agree with them.

The Question Number 7 and responses are as follows:

Do you have ample opportunity to arrange any extracurricular activities in your institution?

\begin{tabular}{|c|c|c|}
\hline \multicolumn{2}{|c|}{ Answer } \\
\hline Yes & No & Total Respondent \\
\hline 06 & 64 & 70 \\
\hline
\end{tabular}

Response: I got the answer "No" from $91.42 \%$ Students and "Yes" from $8.58 \%$ Students.

The Question Number 8 and responses are as follows:

Is there any scope to arrange group circle study to gear up students' capacity in learning English?

\begin{tabular}{|l|l|l|}
\hline \multicolumn{2}{|c|}{ Answer } \\
\hline Yes & No & Total Respondent \\
\hline 06 & 64 & 70 \\
\hline
\end{tabular}

Response: I got answer "No" from 88.88 \% Students and "Yes" from 11.12\% Students.

The Question Number 9 and response are as follow:

Do you think that your classroom size is suitable to study communicative English?

\begin{tabular}{|c|c|c|}
\hline \multicolumn{2}{|c|}{ Answer } \\
\hline Yes & No & Total Respondent \\
\hline 14 & 56 & 70 \\
\hline
\end{tabular}

Response: I got answer "No" from 80 \% Students and "Yes" from $20 \%$ Students.

The Question Number 10 and responses are as follows:

What should we do to develop the skill of learning English language in H.S.C level? Please give your important comments below?

\begin{tabular}{|c|c|c|c|}
\hline \multirow{2}{*}{ Method } & \multicolumn{3}{|c|}{ Answer } \\
\cline { 2 - 4 } & $\begin{array}{c}\text { English } \\
\text { Language } \\
\text { Club }\end{array}$ & $\begin{array}{c}\text { Group Circle } \\
\text { Study \& } \\
\text { extracurricular } \\
\text { Activities }\end{array}$ & $\begin{array}{c}\text { Spoken } \\
\text { Course \& } \\
\text { Free } \\
\text { Writing } \\
\text { Competition }\end{array}$ \\
\hline Motijheel Model & 15 & 50 & 24 \\
High School \& & 50 & 15 & 8 \\
College & & & 0 \\
\hline Notre dame college & 3 & 2 & 0 \\
\hline Other Colleges & 2 & & \\
\hline
\end{tabular}


https://doi.org/10.31426/ijamsr.2018.1.3.134

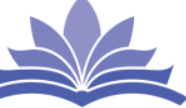

I J A M S R

\section{International Journal of}

Advanced Multidisciplinary Scientific Research (IJAMSR) ISSN:2581-4281

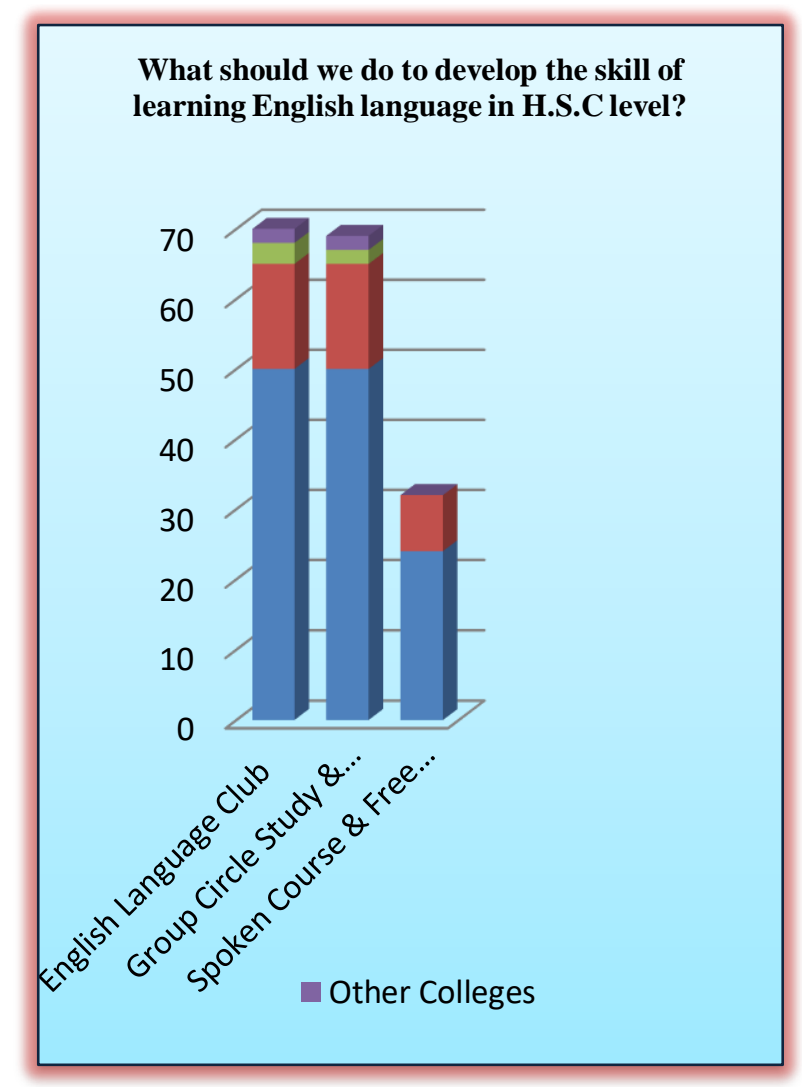

Response: At last the students gave their important proposal to make communicative method_successful and fruitful. Their proposals are stated below:

- To open English language club.

- To open literary club \& debating club.

- To arrange extracurricular activities in their respective college.

- To arrange Group circle study in their college.

- To arrange spoken course, free handwriting competition to develop their skills.

- To arrange classroom dialogue and provide sufficient daily, weekly, quarterly and monthly newspapers \& magazines in their college campus.

\section{Recommendation}

- Group circle study, classroom dialogue, debating competition can be introduced.

- E-Library, internet facility can be increased.

- Free handwriting, reporting, wallpaper can be arranged.

- English language club, Literary club, English learners' forum can be introduced.

- Sufficient English related books, journals, research paper collections can be increased in the library.

- A special class of weak students can be started.

- Strong, multifarious dimension teachers should be appointed in college who can accelerate these programs.

- Students should speak in English on their campus which should be strictly ruled by the college authority.

- Keeping English newspapers, books, journals, magazines etc. in college library would be helpful for the students to increase their knowledge in English language.

- Colleges should organize more English related extracurricular activities. By this students will be influenced to learn more and more about the English language.

- Colleges should organize self test programs like IELTS, GMET etc.

- Colleges should bring new and advanced teaching materials to give better teaching students.

- Colleges should organize a different English forum for the students to help them gather knowledge about English forum.

- Colleges can provide Dictionary software for the students.

- Colleges can take several steps for creating interest in learning English to students.

- Colleges should express necessity to learn English for the students.

- The English Language Teaching method should be technically easy.

- Colleges should provide opportunity to increase vocabulary and practice in speaking English with friends. 
I think above recommendations will be helpful to develop the skills of the English language learner and communicative method can be applied successfully in the respective colleges.

\section{Conclusion}

During my study I have seen some problems and side by side some scopes among the students, in the colleges. The students have much talent, but they do not try to apply it and institutions are not much concerned to provide all the facilities they need in order to improve the English language learning scenario in the higher secondary level in the urban set-up of Bangladesh.

\section{References}

${ }^{1 .}$ www.bangladeshportal.gov.com

2. http://cemca.org/disted/Ainy_Salma_0296.pdf

3. www.asian-efl-journal.com/march_05_sr.ph

4. www.motijheelmodelhighschool\&college.org

5. www.nctb.gov.bd.com

6. www.en.wikipedia.org/wiki/World_Wide_Web

7. Allen, J.P. B. and Widdowson, H. G. 1974, "teaching the communicative use of English", International Review of Applied Linguistics, 12,1, 1-21

8. Allright, R.L.1977a, ' Language learning through communication practice', ELT Docs 76/3, 2-14

9. Brumfit, C.J. 1978, “'Communicative” language teaching: an assessment', in Stevens (ed) 1978.

10. Brumfit, C.J. 1979b, “Communicative” language teaching: an educational perspective'.

Candlin, C.N.1976, 'Communivative language teaching and the debt to pragmatics, Georgetown Round Table 1976.

11. Johnson, K., 1979 'Communicative approaches and communicative processes.'

12.Labov, W.1970, 'The study of language in its social context', Studium Generale, 23, 30-87, reprinted in Giglioli (ed) 1972.

13. M10. unby, J. 1978, Communicative Syllabus Design, Cambridge University Press. 